\title{
A hypersensitive response was induced by virulent bacteria in transgenic tobacco plants overexpressing a plant ferredoxin-like protein (PFLP)
}

\author{
Hsiang-En Huang ${ }^{\mathrm{a}, \mathrm{b}}$, Mang-Jye Ger ${ }^{\mathrm{c}}$, Mei-Kuen Yip ${ }^{\mathrm{a}}$, Chao-Ying Chen ${ }^{\mathrm{b}}$, \\ Ajay-Kumar Pandey ${ }^{a}$, Teng-Yung Feng ${ }^{\text {a,* }}$ \\ ${ }^{a}$ Institute of Botany, Academia Sinica, Nankang, Taipei 115, Taiwan, ROC \\ ${ }^{\mathrm{b}}$ Department of Pathology and Microbiology, National Taiwan University Taipei 106, Taiwan, ROC \\ ${ }^{\mathrm{c}}$ Department of Life Science, National University of Kaohsiung, Kaohsiung 811, Taiwan, ROC
}

Accepted 28 May 2004

\begin{abstract}
The hypersensitive response (HR) displayed by resistance plants against invading pathogens is a prominent feature of an incompatible plant pathogen interaction. It has been shown that tobacco cell cultures transgenic for a plant ferredoxin-like protein (PFLP) that functions as an electron acceptor of Photosystem I increased harpin-mediate HR. In this work we report increased bacterial disease resistance of $p f l p$ transgenic tobacco. Compared to the controls, four distinctive characteristics were found in the $p f p$-transgenics after inoculation with virulent bacterial cells Erwinia carotovora subsp. carotovora and Pseudomonas syringae pv. tabaci: (i) instead of typical disease symptoms, an HR-like necrosis was observed; (ii) the proliferation of the virulent pathogen was highly retarded; (iii) the expression of hsr203j, an HR marker gene, was apparently induced; (iv) $\mathrm{H}_{2} \mathrm{O}_{2}$ accumulation was induced immediately. Together, those results demonstrate that enhanced production of PFLP in the transgenic plant conditions the induction of a hypersensitive response during compatible pathogen attack.
\end{abstract}

(C) 2004 Elsevier Ltd. All rights reserved.

Keywords: Ferredoxin-like protein; Erwinia carotovora subsp. carotovora; Pseudomonas syringae pv. tabaci; hsr203j

\section{Introduction}

Avirulent pathogens elicit a rapid collapse of the challenged host cells in the so-called hypersensitive response (HR) that results in a restricted necrotic lesion from surrounding healthy tissue. Although some host tissue is damaged during the HR process, the localized host cell death contributes to the limitation of pathogen spread $[22,24,26]$. A battery of inducible defense-related responses often accompanies an HR, including the generation of antibiotics [5], an oxidative burst [37] and enzymes involved in the general phenylpropanoid pathway [9]. Many defense-related signal molecules, such as salicylic acid, ethylene and jasmonic acid was also induced

\footnotetext{
* Corresponding author. Tel.: +886-2-26521867; fax: +886-2-27827954.

E-mail address: natfarm@gate.sinica.edu.tw (T.-Y. Feng).
}

under HR condition [27]. These molecules have emerged as a key signal in the establishment of disease resistance and are able to protect the plant against further pathogen infection [8,11].

Harpin is one group of glycine-rich, cysteine-lacking, heat-stable proteins that can elicit HR in the absence of bacteria [41]. Three genera of plant bacterial pathogens, Erwinia, Pseudomonas, and Ralstonia spp. export harpins via the type III protein secretion system [3,12]. Genetic evidence indicates that harpins may play a minor role in bacterial elicitation of the HR, but it may assist the delivery of other pathogenesis proteins across the plant cell wall [12]. $\mathrm{HR}$ induced by harpin from Erwinia amylovora $\left(\mathrm{HrpN}_{\mathrm{Ea}}\right)$ or Pseudomonas syringae $\mathrm{pv}$. syringae $\left(\mathrm{HrpZ}_{\mathrm{Pss}}\right)$ was prevented by inhibition of calcium influx and ATPase activity in tobacco cell suspensions [16]. Harpin has a pronounced effect on the plasmalemma, affecting $\mathrm{H}^{+}$-ATPase, ion channels or membrane carriers [30,33]. It also causes 
$\mathrm{K}^{+}$efflux and extracellular alkalization in cell suspension cultures but not in protoplasts [19]. A secret able form of harpin from $P$. syringae pv. phaseolicola can elicit HR when expressed endogenously in plants [39]. These results indicate that the site of harpin action is the plant cell membrane/cell wall.

Previously, we reported that PFLP (plant ferredoxin like protein) was able to increase the generation of harpin pss $^{-}$ mediated AOS and HR in tobacco suspension cells [7]. However, it is not know whether higher AOS generation in transgenic plant would assist in bacterial pathogen defense. In this paper we generated $p f p$ transgenic tobacco to study the effect on defense against plant pathogenic bacteria. The pflp transgenic tobacco showed higher sensitivity to harpin than the wild type. When inoculated with the virulent pathogens Erwinia carotovora subsp. carotovora and Pseudomonas syringae pv. tabaci, the interaction was incompatible and the pflp transgenic tobacco showed disease resistance. Moreover, the accumulation of $\mathrm{H}_{2} \mathrm{O}_{2}$ and the expression level of HR marker gene $h s r 203 j$ were highly induced in $p f p$-transgenic lines. These results imply that an enhanced amount of PFLP in the transgenic plants condition the induction of a hypersensitive response during virulent pathogen attack.

\section{Materials and methods}

\subsection{Construction of the transformation vector}

The coding sequence of $p f p$ gene was amplified from the sweet pepper clone [7] by PCR with the following primers: B5-SPF: 5'-CGG GAT CCC GAT GGC TAG TGT CTC AGC TAC CA-3', and S3-PF: CGA GCT CGT TAG CCC XCG AGT TCT GCT TCT-' 3 . The PCR product was digested with BamH I and SacI. The full-length $p f l p$ fragment replaced the GUS protein coding sequence from pBI121 vector with CaMV 35S promoter (Clontech, Palo Alto, CA, USA.), and the insert was verified by DNA sequencing. The resultant plasmid, pBISPFLP, was then transformed into Escherichia coli DH5 $\alpha$.

\subsection{Generation of transgenic tobacco lines}

Agrobacterium tumefaciens $\mathrm{C} 58 \mathrm{C} 1$ was transformed with pBISPFLP vectors as described by Holsters et al. [17]. Transformation of tobacco (Nicotiana tabacum cv. Xanthi) was performed by the standard leaf disc transformation method using kanamycin selection $(100 \mu \mathrm{g} / \mathrm{ml})$ [18]. PCR analysis and DNA gel blotting confirmed six independent transformant lines. All transgenic plants were grown in a growth chamber $(16 \mathrm{~h}$ light/ $8 \mathrm{~h}$ dark at $30^{\circ} \mathrm{C}$ ). The irradiances of growth chamber are $48 \mu \mathrm{mol} \mathrm{m}^{-2} \mathrm{~s}^{-1}$. Two transgenic lines were self-fertilized and the seeds were collected for seeding and PCR analysis.

\subsection{Extraction and gel blot analysis of DNA, RNA, and protein}

Genomic DNA was extracted from young leaf tissue by the Qiagen genomic kit protocol (Qiagen). Digestion with restriction enzymes, electrophoretic separation on agarose gels, and transfer to nylon membranes (Boehringer Mannheim) were performed by using standard procedures [35]. Membranes were hybridized at $65^{\circ} \mathrm{C}$ with the full length NPT II marker probe PCR-label with digoxigenin11-dUTP (Boehringer Mannheim) according to the manufacturer's protocols. After hybridization, membranes were washed under high stringency conditions $(2 \times \mathrm{SSC}, 0.1 \%$ SDS) and detected using the DIG luminescent detection kit (Boehringer Mannheim).

Total RNA was isolated from tobacco leaves using the Qiagen Plant RNA Kit (Qiagen) and quantified by spectrophotometry, assuming $\mathrm{A}_{260}=40 \mu \mathrm{g} / \mathrm{ml}$ [35]. Total RNA $(15 \mu \mathrm{g})$ was electrophoresed through $1 \%$ agarose/ formaldehyde gels and then transferred onto nylon membranes. Membranes were hybridized at $55^{\circ} \mathrm{C}$ overnight with $h s r 203 j$ probes PCR-label with digoxigenin-11-dUTP (Boehringer Mannheim) according to the manufacturer's protocols. After hybridization, membranes were washed under high stringency conditions and detected using the DIG Luminescent detection kit (Boehringer Mannheim).

Proteins were extracted by homogenizing $0.2 \mathrm{~g}$ of fresh leaf tissue in $0.5 \mathrm{ml}$ Tris buffer $(150 \mathrm{mM} \mathrm{NaCl}, 50 \mathrm{mM}$ Tris $\mathrm{pH}$ 7.5 ) using a plastic pestle fitted to a $1.5 \mathrm{ml}$ centrifuge tube. The protein concentrations of the samples were determined with Coomassie brilliant blue dye using a microassay method as recommended by the manufacturer (BioRad). Two micrograms of each protein sample were electrophoresed through gels containing $12.5 \%$ polyacrylamide plus SDS (SDSPAGE). These gels were then either stained with Coomassie blue or electro-transferred onto nitrocellulose membranes using the BioRad blue tank method. PFLP proteins were detected on Western blots using anti-PFLP antibodies followed with mouse anti-rabbit IgG-peroxidase conjugate.

\subsection{Harpin ${ }_{P s s}$ preparation and plant hypersensitive response assay}

The harpin ${ }_{\text {Pss }}$ clone was provided by Dr H.-C. Huang at the Agricultural Biotechnology Laboratories, National Chung-Hsien University, Taiwan. Harpin Pss protein was extracted according to He et al. [16]. Escherichia coli DH5 $\alpha$ (pSY10) which harbors the harpin ${ }_{\text {Pss }}$ gene (hrpZ) was grown in Luria Broth containing ampicillin $(50 \mu \mathrm{g} / \mathrm{ml})$ at $37{ }^{\circ} \mathrm{C}$ in the dark with shaking overnight in the presence of isopropylthio- $\beta$-D-galactoside. To obtain harpin ${ }_{\text {Pss }}$, the bacteria were first washed and sonicated for $30 \mathrm{~s}$ in $10 \mathrm{mM}$ phosphate buffer $\mathrm{pH} 6.5$ and boiled for $10 \mathrm{~min}$. After boiling, the extracts were centrifuged at $10,000 \times g$ for $10 \mathrm{~min}$. Supernatants were desalted by a Microconcentrator (Amicon) and stored at $4{ }^{\circ} \mathrm{C}$. 
The HR assay was performed according to Huang et al. [20]. Fully expanded tobacco leaves were wounded to form tiny pricks on the lower surface of the leaves by a 25 -gauge needle. Harpin ${ }_{\text {Pss }}$ was prepared in $50 \mathrm{mM}$ Tris buffer (pH 7.5) and infiltrated by pressing a $1 \mathrm{ml}$ syringe without a needle to the prick. The infiltrated plant was incubated in a growth chamber $\left(16 \mathrm{~h}\right.$ light $/ 8 \mathrm{~h}$ dark at $\left.25^{\circ} \mathrm{C}\right)$.

\subsection{Transgenic tobacco resistance assays}

All transgenic tobacco resistance assays were carried out with $\mathrm{T} 2$ progenies of the transgenic plants in independent experiments. Fully expanded upper leaves of plants, approximately 80-days old, were used for infection with pathogen. Inoculations with Pseudomonas syringae pv. tabaci and Erwinia carotovora subsp. carotovorawere performed. Each inoculation was repeated four times in individual plants of each transgenic line. Bacteria inside the leaf discs were released by grinding the infiltration area in sterile water in a microfuge tube and then plated on Nutrient Broth agar plates. The plates were cultured at $30{ }^{\circ} \mathrm{C}$ overnight, and the colonies were counted the following day.

\subsection{Determination of $\mathrm{H}_{2} \mathrm{O}_{2}$}

$\mathrm{H}_{2} \mathrm{O}_{2}$ was determind according to method of Jana and Choudhuri [21]. Tobacco leaves $(100 \mathrm{mg})$ were homogenized with $0.6 \mathrm{ml}$ of $50 \mathrm{mM}$ phosphate buffer $(\mathrm{pH} \mathrm{6.5)}$ with $10 \mathrm{mM}$ 3-amino-1, 2, 4-triazole. The homogenates were centrifuged at $6000 \mathrm{~g}$ for $25 \mathrm{~min}$. Titanium sulphate $(0.2 \mathrm{ml}$ of $0.1 \%$ ) in $20 \%$ (v/v) $\mathrm{H}_{2} \mathrm{SO}_{4}$ was added to the supernatant and centrifuged at $6000 \mathrm{~g}$ for $15 \mathrm{~min}$. The intensity of the yellow colour of the supernatant was measured at $410 \mathrm{~nm}$ to determine the level of $\mathrm{H}_{2} \mathrm{O}_{2}$.

\section{Results}

\subsection{Screening and expression analysis of pflp transgenic tobacco plants}

Tobacco plants expressing heterologous $p f p$ gene isolated from sweet pepper were generated by Agrobacterium-mediated transformation. $\mathrm{pBI}$ based plasmid construct containing sweet pepper $p f p$ cDNA was prepared for tobacco transformation. (Fig. 1). Viable transformation

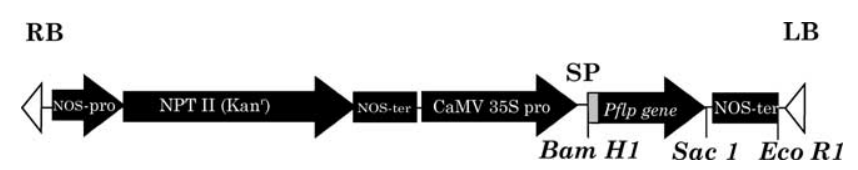

Fig. 1. Map of the relevant portions of the transformation plasmids. pBR-spflp, NOS-pro=the promoter region of A. tumefaciens nopaline synthase, NOS-ter = the terminator region of the same gene, NPT II=the coding sequence of neomycin phosphotransferase II gene, CaMV 35Spro $=$ the CaMV $35 \mathrm{~S}$ promoter sequence, $\mathrm{pflp}=$ the coding sequence for the sweet pepper PFLP and $\mathrm{SP}=$ signal peptide of sweet pepper PFLP.

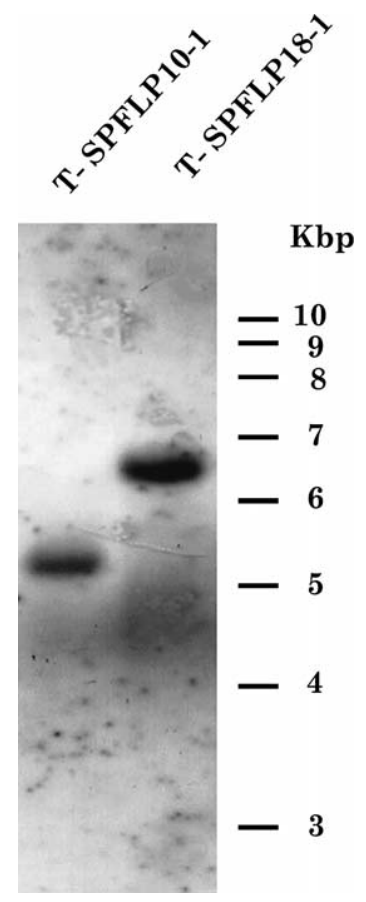

Fig. 2. Gel blots analysis of genomic DNA, DNA gel blot analysis of T-SPFLP transformed tobacco using NPT II cDNA as probe. Genomic DNA $(15 \mu \mathrm{g})$ was digested with EcoR I for T-SPFLP10-1 and T-SPFLP18-1 as indicated and subjected to Southern blot analysis.

lines were selected and designated as T-SPFLP. In order to identify the distribution of $p f p$ transgene in transgenic tobacco genomes, genomic DNA was extracted from the transgenic lines and subjected to Southern analysis. Given that wild type tobacco contains the ferredoxin gene [7], neomycin phosphotransgeraseII (NPT II) cDNA was used as a probe to identify the transgenic loci. Genomic DNA from T-SPFLP10-1 and T-SPFLP18-1 were digested with EcoRI restriction enzyme. Fig. 2 showed that, after probing with the NPTII cDNA probe, DNA of the transgenic tobacco lines T-SPFLP10-1 and T-SPFLP18-1 exhibit one band, respectively. The patterns of Southern blotting suggest that T-SPFLP10-1 and T-SPFLP18-1 result from independent transformation events and incorporate the $p f p$ transgene at different chromosomal locations. Western blot analysis showed that PFLP protein levels in T-SPFLP transformants was two to three fold increased compared to the controls (Table 1).

Table 1

Quantitative PFLP expression levels in transgenic tobacco

\begin{tabular}{ll}
\hline Transgenic lines & Protein (fold) \\
\hline T-SPFLP10-1 & $3.13 \pm 0.21$ \\
T-SPFLP18-1 & $2.80 \pm 0.58$ \\
Wild type & $1.00 \pm 0.21$ \\
\hline
\end{tabular}

${ }^{a}$ Protein levels were determined with western blot. The PFLP protein level of wild type tobacco was defined as 1 . 
A

T-SPFLP10-1

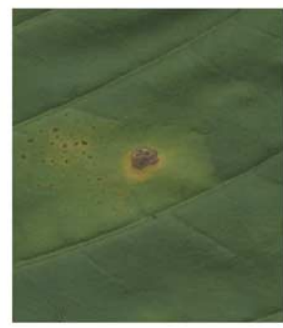

B

$h s r 203 j$

\section{T-SPFLP10-1}
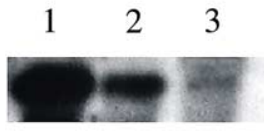

Wt

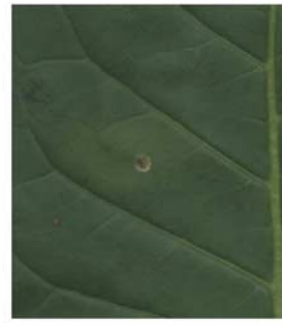

Wt

$1 \quad 2 \quad 3$
rRNA

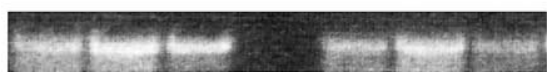

Fig. 3. The harpin ${ }_{\mathrm{Pss}}-$ mediated hypersensitive response (HR) in transgenic and wild type tobacco. (A) Low concentration of harpin Pss $_{\text {induced slight }}$ HR in transgenic tobacco. Harpin ${ }_{\text {Pss }}(0.1 \mu \mathrm{g})$ was infiltrated into transgenic (T-SPFLP10-1) and wild type (Wt) tobacco leaves. Photograph was taken 2 days post infiltration. (B) Induction of $h s r 203 j$ gene expression by harpin ${ }_{\text {Pss. }}$. The transgenic (T-SPFLP10-1) and wild type (Wt) tobacco were infiltrated with $10 \mu \mathrm{g}$ (lane 1), $1 \mu \mathrm{g}$ (lane 2) and $0.1 \mu \mathrm{g}$ (lane 3 ) of harpin Pss. Total RNA in the infiltration areas of tobacco leaves were extracted after $12 \mathrm{~h}$. RNA blots ( $15 \mu \mathrm{g}$ per lane) were probed with the $h s r 203 j$ cDNA probe. Ethidium bromide staining of rRNA was used to verify the loaded amount of total RNA.

\section{2. pflp transgenic plants showed a high sensitivity to harpin $_{P s s}$}

In order to investigate the relationship between the PFLP and harpin ${ }_{\text {Pss }}$-mediated HR in vivo, different dosages of harpin $_{\text {Pss }}$ were infiltrated into the intercellular spaces of transgenic and wild type tobacco leaves and HR necroses were subsequently examined. After infiltration with 10 and $1 \mu \mathrm{g}$ harpin Pss $_{\text {over }} 24 \mathrm{~h}$, in the transgenic line leaves showed HR necroses almost to the full extent of the infiltration area, but wild type tobacco leaves exhibited much less HR necrosis. Even infiltration using lower concentrations of harpin ${ }_{\mathrm{Pss}}$ $(0.1 \mu \mathrm{g})$ over $24 \mathrm{~h}$ in the transgenic line leaves showed a slight HR necrosis but not in wild type leaves (Fig. 3A).

The HR molecular marker gene hsr203j [31,32] that accumulates specifically in tissues undergoing HR was examined. After infiltration with 10 and $1 \mu \mathrm{g}$ of harpin ${ }_{\text {Pss }}$ over $12 \mathrm{~h}$, the $h s r 203 j$ messenger accumulation was three fold increase in transgenic lines when compared to the wild type. When infiltrated with $0.1 \mu \mathrm{g}$ harpin ${ }_{\text {Pss }}$, the activation of $h s r 203 j$ could be detected in transgenic tobacco but not in wild type (Fig. 3B). These results implied that the pflp transgenic tobacco have higher sensitivity to the HR elicitor.

\section{3. pflp transgenic tobacco exhibited resistance to virulent bacterial pathogens}

To determine the effects of the $p f p$ gene on plant disease resistance, two individual transgenic lines were challenged

Wt
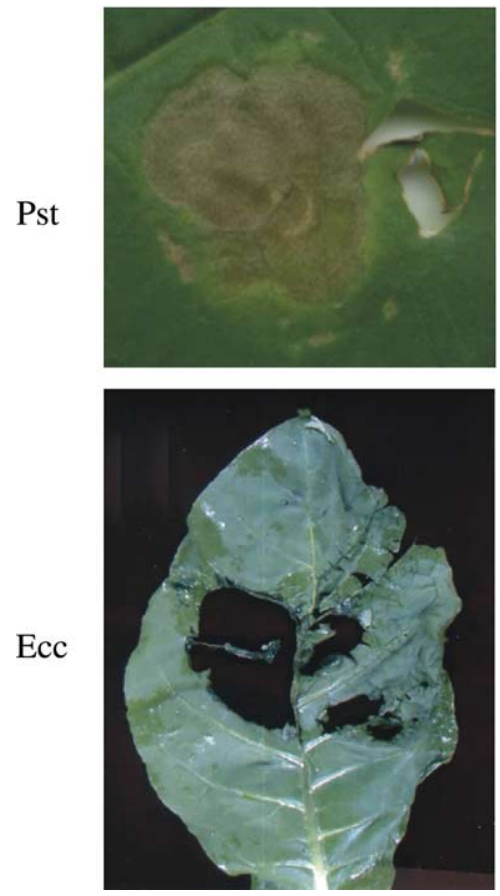

T-SPFLP18-1
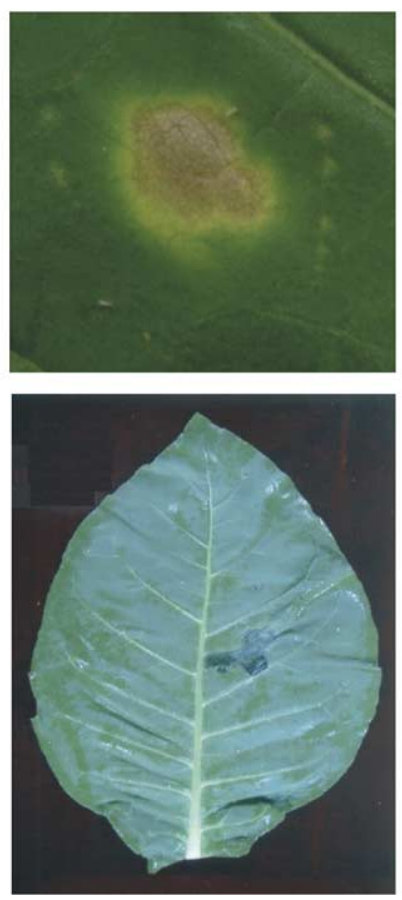

T-SPFLP10-1
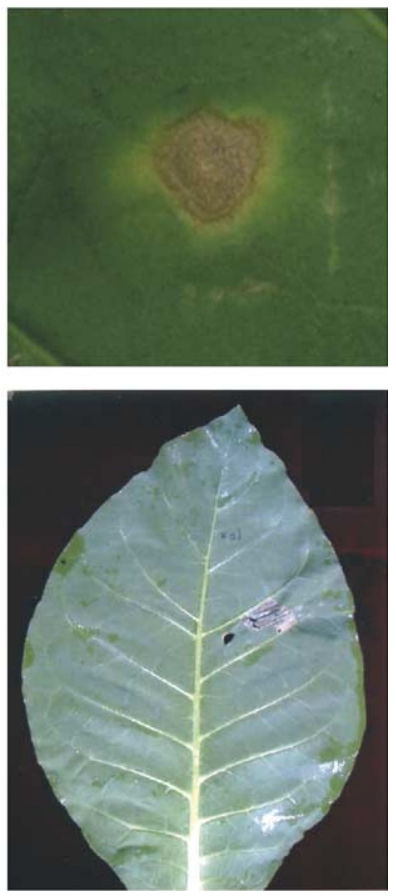

Fig. 4. Resistance of $p f p$ transgenic tobacco to virulent pathogens. Fully expanded upper leaves of transgenic (T-SPFLP18-1, TSPFLP10-1) and control tobacco $(\mathrm{Wt})$ were infiltrated with $100 \mu \mathrm{l}$ of bacterial suspension P. syringae pv. tabaci $\left(1.0 \times 10^{8} \mathrm{cfu} / \mathrm{ml}\right)(\mathrm{upper}$ panel) or E. carotovora subsp. carotovora $\left(1.0 \times 10^{8} \mathrm{cfu} / \mathrm{ml}\right)$ (lower panel). Photographs of upper panel were taken 5 days post inoculation and lower panel were taken 2 days post inoculation. 

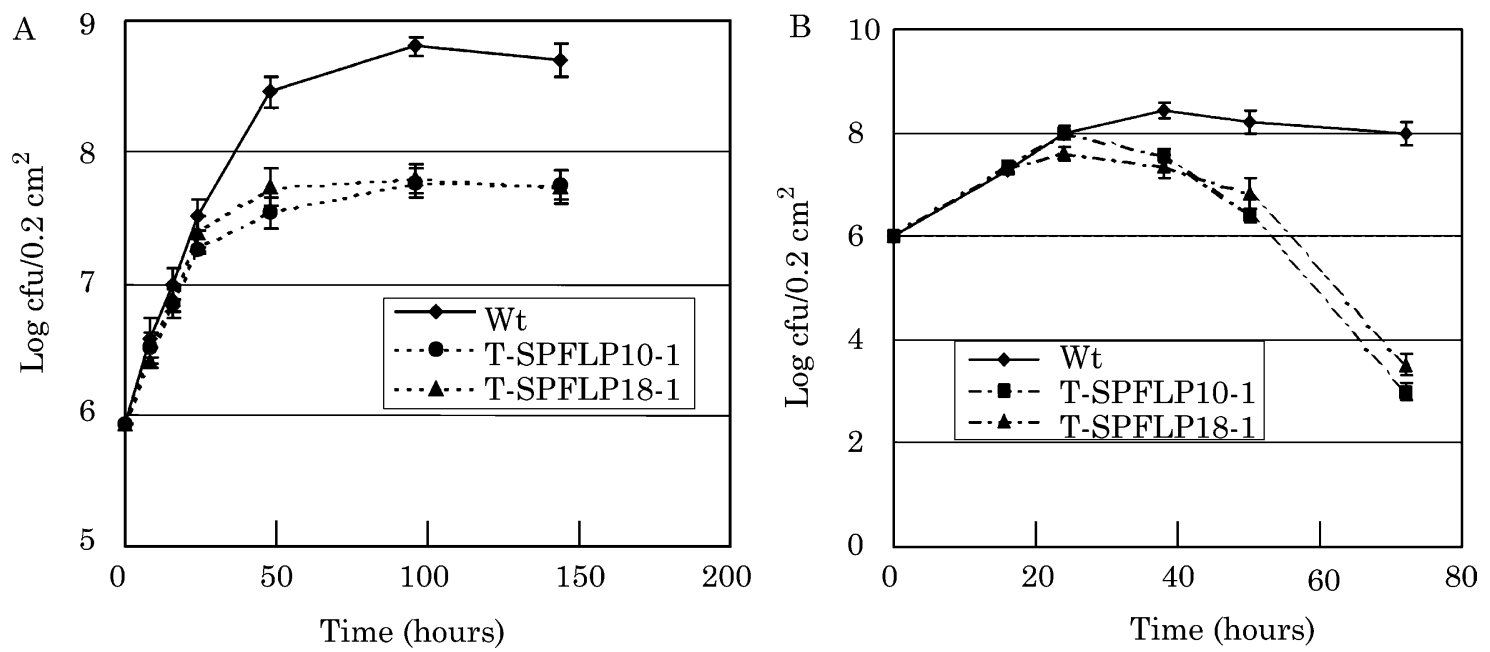

Fig. 5. The multiplication of bacterial pathogens were inhibited in $p f p$ transgenic tobacco. Fully expanded upper leaves of two transgenic lines T-SPFLP10-1, T-SPFLP18-1 and control tobacco (wt) were infiltrated with $100 \mu \mathrm{l}$ of bacterial suspension of $P$. syringae pv. tabaci (1.0 $\left.\times 10^{8} \mathrm{cfu} / \mathrm{ml}\right)(\mathrm{A})$ or E. carotovorasubsp. carotovora $\left(1.0 \times 10^{8} \mathrm{cfu} / \mathrm{ml}\right)$. (B) Bacterial populations were detected on successive times post inoculation. Data presented are mean and standard deviation of four individual plants.

with the virulent bacterial plant pathogens $P$. syringae pv. tabaci or E. carotovorasubsp. carotovora. The wild fire symptom occurred in wild type 3 -days post $P$. syringae pv. $\operatorname{tabaci}\left(1 \times 10^{8} \mathrm{cfu} / \mathrm{ml}\right)$ inoculation and the symptoms expanded continuously. However, the leaves of transgenic lines exhibited HR-like symptoms after 1-day post inoculation and this necrosis was dehydrated and limited in the infection site, even on 7-days post inoculation (Fig. 4A-C). Transgenic plants were also evaluated for resistance to bacterial soft rot disease caused by E. carotovora subsp. carotovora. E. carotovora subsp. carotovora $\left(1 \times 10^{8} \mathrm{cfu} / \mathrm{ml}\right)$ cause tissue maceration in wild type tobacco leaves (Fig. 4D). As shown in Fig. 4E and F, pflp transgenic tobacco leaves exhibited HR-like necrosis and the necrosis was limited even after 2-days post inoculation. Bacterial populations in the infiltrated areas were calculated post inoculation at different times. A ttest demonstrated that differences in pathogen number between transgenic and wild type tobacco 2-days post infections were significant $(P<0.05)$. Postinoculation (2-days), the population of $P$. syringae pv. tabaci and E. carotovora subsp. carotovora in the wild-type tobacco was approximately 10 times higher than that found in the transgenic lines (Fig. 5). These results indicated that overexpression of $p f p$ in transgenic tobacco could enhances resistance against both kinds of virulent pathogens, E. carotovora subsp. carotovora and $P$. syringae pv. tabaci.

\section{4. hsr203j gene expression was induced in transgenic tobacco by virulent pathogen infections}

pflp transgenic tobacco plants showed HR-like necrosis when inoculated with compatible pathogens. To make sure those necroses was due to HR, an HR molecular marker gene $h s r s 203 j$ was monitored after virulent pathogen inoculated in transgenic tobacco. The leaves of $p f p$ transgenic (SPFLP18-1) and wild type tobacco were infiltrated with $100 \mu$ of E. carotovorasubsp. carotovora and $P$. syringae pv. tabaci, respectively $\left(1.0 \times 10^{7} \mathrm{cfu} / \mathrm{ml}\right)$. Total RNA in the infiltration areas of tobacco leaves were extracted and probed with the $h s r 203 j$. The HR marker gene $h s r 203 j$ was highly induced at $6 \mathrm{~h}$ post $E$. carotovora subsp. carotovora inoculation and this induction was continued over $24 \mathrm{~h}$ in the $p f t p$ transgenic tobacco (Fig. 6A). Northern blot analysis was also performed when tobacco leaves were challenged with compatible

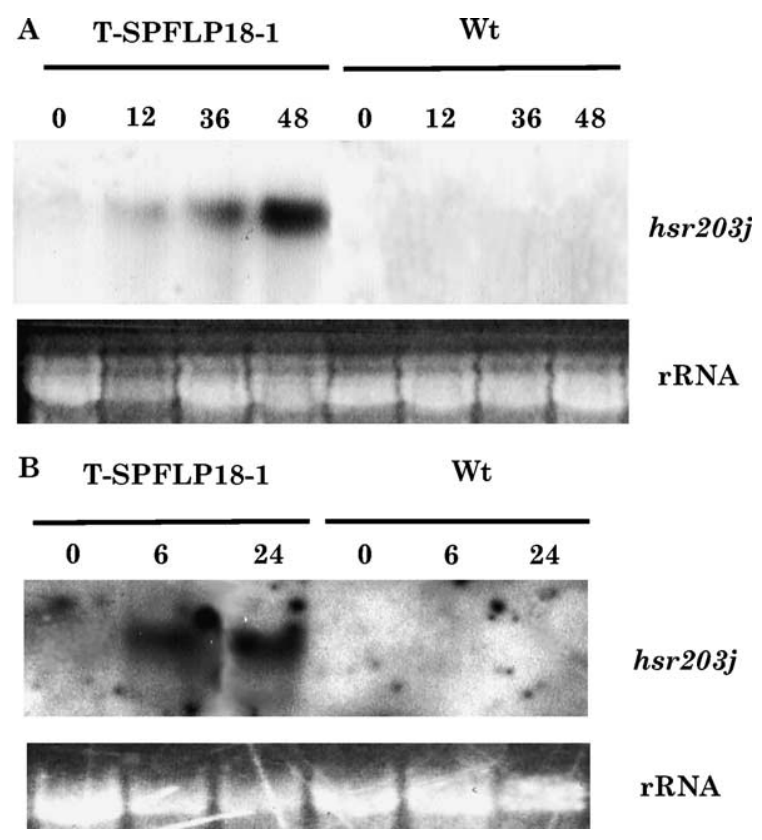

Fig. 6. Induction of $h s r 203 j$ gene expression in transgenic tobacco by virulent pathogen infected. The transgenic (SPFLP18-1) and wild type (wt) tobacco were infiltrated with $100 \mu \mathrm{l}$ of E. carotovora subsp. carotovora(A) and P. syringae pv. tabaci (B) individual $\left(1.0 \times 10^{7} \mathrm{cfu} / \mathrm{ml}\right)$. Total RNA in the infiltration areas of tobacco leaves was extracted at the time points indicated. RNA blots $(15 \mu \mathrm{g}$ per lane) were probed with the $h s r 203 j \mathrm{cDNA}$ probe. Ethidium bromide staining of rRNA was use to verify the loaded amount of total RNA. 


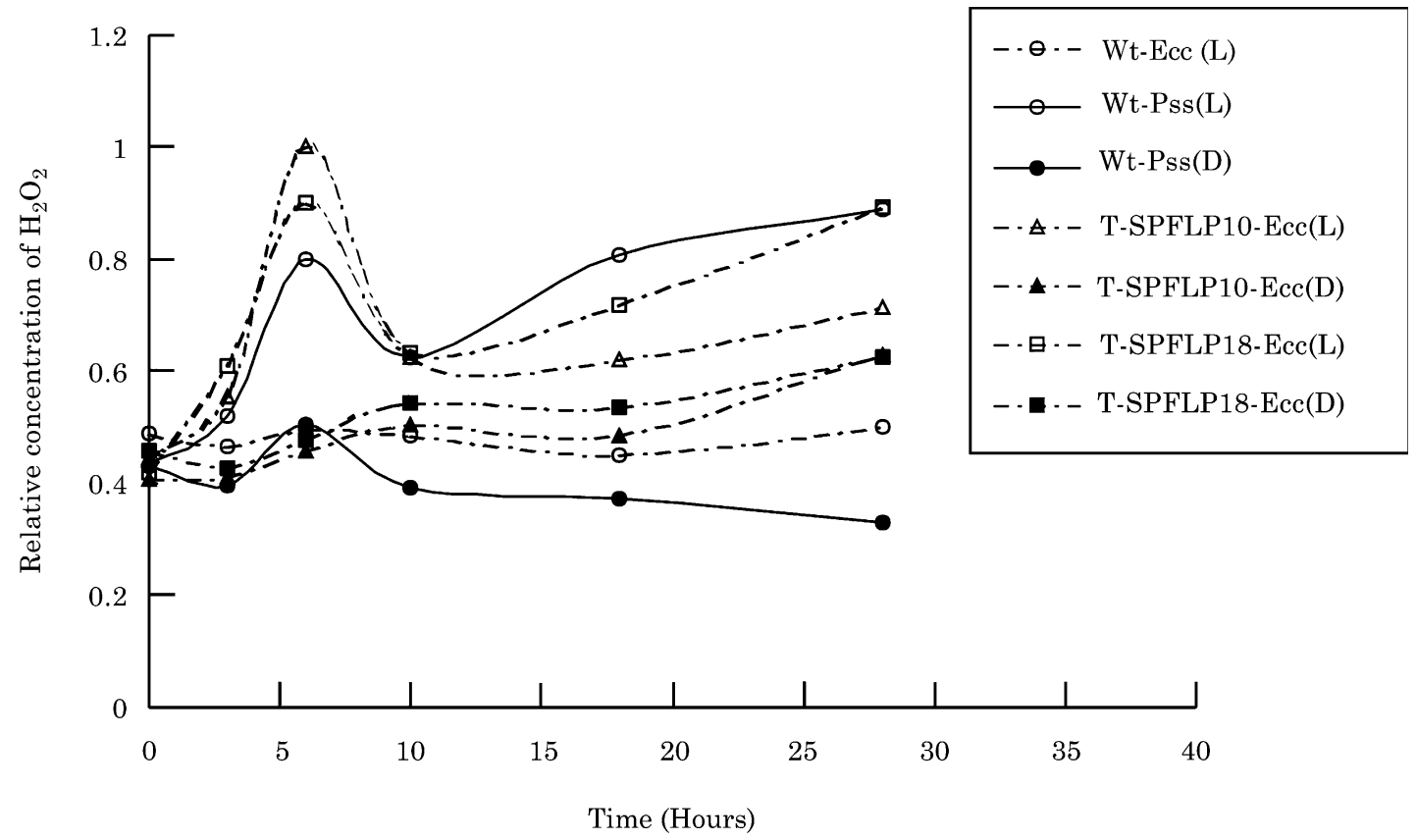

Fig. 7. $\mathrm{H}_{2} \mathrm{O}_{2}$ was induced in transgenic tobacco by virulent pathogen infections. The wild type (Wt) and transgenic tobacco plants (T-SPFLP10, T-SPFLP18) were infiltrated with $100 \mu \mathrm{l}$ of E. carotovora subsp. carotovora (Ecc) and Pseudomonas syringae pv. syringae (Pss) $\left(1.0 \times 10^{6} \mathrm{cfu} / \mathrm{ml}\right)$ under light $(\mathrm{L})$ and dark(D) conditions individual. $\mathrm{H}_{2} \mathrm{O}_{2}$ in the infiltration areas of tobacco leaves was extracted at the time points indicated. Data were expressed as mean of relative values from four individual plants.

pathogen $P$. syringae pv. tabaci (Fig. 6B). The hsr203j was induced at $12 \mathrm{~h}$ post inoculation and this induction was continued over $48 \mathrm{~h}$. It indicates that a virulent bacterial pathogen indeed induce HR maker gene in the $p f p$ transgenic plants.

\section{5. $\mathrm{H}_{2} \mathrm{O}_{2}$ was induced in transgenic tobacco by virulent pathogen infections}

The rapid production of peroxide $\left(\mathrm{H}_{2} \mathrm{O}_{2}\right)$ by plant is one of the most striking events during the early phase of the HR. To evaluate the production of $\mathrm{H}_{2} \mathrm{O}_{2}$ in $p f p$ transgic tobacco, two different $p f p$ transgenic tobacco lines (T-SPFLP18, T-SPFLP10) were infiltrated with $100 \mu \mathrm{l}$ of E. carotovora subsp. carotovora $\left(1.0 \times 10^{6} \mathrm{cfu} / \mathrm{ml}\right)$ and the yield of $\mathrm{H}_{2} \mathrm{O}_{2}$ was measured as describe by Jana and Choudhuri [21]. The concentration of $\mathrm{H}_{2} \mathrm{O}_{2}$ was highly increased at $6 \mathrm{~h}$ post E. carotovora subsp. carotovora inoculation and this induction was continued over $10 \mathrm{~h}$ in the $p f p$ transgenic under light condition. This accumulation of $\mathrm{H}_{2} \mathrm{O}_{2}$ was similar to avirulent pathogen Pseudomonas syringae pv. syringae inoculated in the wild type tobacco (Fig. 7). The concentration of $\mathrm{H}_{2} \mathrm{O}_{2}$ was estimated to be $80-120 \mathrm{mM}$ at the peak. However, no $\mathrm{H}_{2} \mathrm{O}_{2}$ accumulation was observed when inoculation with the avirulenct pathogen was followed by incubation in the dark.

\section{Discussion}

AOS accumulation has been shown to be required for plant pathogen defense [40]. Nevertheless, not all cases of AOS accumulation increase in transgenic plant improve plant disease resistance. For example, AS1 transgenic tobacco that increases AOS accumulation was more sensitive to HR elicitor. However, the lesion cause by the virulent pathogen P. syringae pv. tabaci was more serious in AS1 transgenic tobacco than in the wild type [28]. Previously, we reported that PFLP was able to increase the generation of harpin pss $^{-}$ mediated AOS and HR in tobacco suspension cells [7]. To understand the effect of overexpression $p f l p$ in transgenic tobacco on disease resistance, $p f l p$ transgenic tobacco was generated and challenged with virulent bacterial pathogens.

The growth of $P$. syringae pv. tabaci in the $p f p$ transgenic tobacco was significantly inhibited when compared with wild type tobacco (Fig. 5). The visible necrosis induced by $P$. syringae pv. tabaci was restrained significantly in the $p f p$ transgenic tobacco (Fig. 4). To further confirm that this necrosis was due to HR, the HR marker gene $h s r 203 j$ expression pattern was monitored. When inoculated with $P$. syringae pv. tabaci the $h s r 203 j$ was activated in $p f p$ transgenic tobacco but not in wild type (Fig. 6B). Additionally, Southern analysis showed that the $p f p$ transgene incorporated at different loci in two independent transgenic lines (Fig. 2). Thus, the disease resistance to the virulent pathogens was due to $p f p$ transgene and not as a result from rearrangement of the transgene at the specific locus of integration. These results indicated that $p f p$ transgenic tobacco has acquired disease resistance and this disease resistance was obtained by the induction of HR.

Earlier we reported that rice and the orchid Oncidium which overexpressed an PFLP transgene from sweet pepper 
showed increased disease resistance. [25,38]. In this study, to confirm that this disease resistance was generally specific, another bacterial pathogen, E. carotovora subsp. carotovora was challenged in $p f p$ transgenic tobacco. E. carotovora subsp. carotovora is a wide host range bacterial plant pathogen that rapidly rots affected tissue. Although it has an inner typeIII secretion system region coding for the elicitor harpin, it never induces HR because the amount of secreted harpin is too low $[4,23,29,34]$. When E. carotovora subsp. carotovora inoculated in the $p f p$ transgenic tobacco, the HR marker gene $h s r 203 j$ were also activated (Fig. 6A). This result implies that not only $P$. syringae pv. tabaci but also $E$. carotovora subsp. carotovora could induce HR resistance in pflp transgenic tobacco. We also demonstrated that $p f p$ transgenic tobacco was more sensitive to low amount of harpin (Fig. 3). We surmised that pflp transgenic tobacco could be induced HR more easily by low amounts of harpin and thus show an HR against virulent bacterial pathogens.

Ferredoxin-I plays as a role of photosynthetic electron transport by supplying electrons for the reduction of NADP ${ }^{+}$ to NADPH and under ertain circumstances can be involved in the production of AOS [1]. PFLP is able to increase the generation of AOS in tobacco suspension cells [7]. In this paper we measure the $\mathrm{H}_{2} \mathrm{O}_{2}$ generated in pflp transgenic tobacco after virulent pathogen infection. When inoculated with the virulent pathogens Erwinia carotovora subsp. carotovora, the accumulation of $\mathrm{H}_{2} \mathrm{O}_{2}$ was highly induced in $p f p$-transgenic lines. This result was similar to an avirulent pathogen Pseudomonas syringae pv. syringae inoculated in the wild type tobacco (Fig. 7). $\mathrm{H}_{2} \mathrm{O}_{2}$ generation in the $\mathrm{HR}$ is usually considered to be highly associated with the light condition [42], In this study, the $\mathrm{H}_{2} \mathrm{O}_{2}$ accumulation of $p f p$ transgenic tobacco plants induced by the virulent pathogen never occurred under dark conditions. These results imply that the HR induced by the virulent pathogen in $p f l p$ transgenic tobacco is light dependent.

Exploitation of plant endogenous defense mechanism is a useful strategy to create disease resistance traits $[6,9]$. A number of reports have indicated that expression of elicitors or $a v r$ gene products in transgenic plants can trigger an HR that generates broad-spectrum disease resistance to virulent pathogens $[2,10,13,15,36]$. The potential application of this strategy is limited, because HR is a programmed cell death process in which the plant depletes many energy resources to synthesize defense-related compounds. Our strategy has the advantage that overexpression of $p f l p$ in transgenic plants does not trigger any macroscopic or microscopic spontaneous HR directly before pathogen infection. However, overexpression of $p f p$ in transgenic plant to protect from bacterial infection was limited by the internal regulatory elements of PFLP in the young seedling [14]. In young seedlings, ferredoxin could not accumulate very well in the transgenic tobacco even under control of $35 \mathrm{~S}$ promoter (data not shown).

In summary, we have demonstrated the utility of $p f p$ in transgenic tobacco to increase disease resistance. HR was induced in $p f l p$ transgenic tobacco against two different genera of virulent pathogens. Using this approach, transgenic plants of more broad disease resistance could be generated for the future.

\section{Acknowledgements}

We would like to thank Dr Pontier from Laboratoire de Biologie Moleculaire des Relations Plantes/Microorganismes, France for providing the $h s r 203 j$ clone. This work was supported by grants to T.-Y. Feng from Academia Sinica, Taiwan, Republic of China.

\section{References}

[1] Biehler K, Fock H. Evidence for the contribution of the Mehlerperoxidase reaction in dissipating excess electrons in drought-stressed wheat. Plant Physiol 1996;112:265-72.

[2] Büschges R, Hollricher K, Panstruga R, Simons G, Wolter M, Frijters A, Van Daelen R, Van der Lee T, Diergaarde P, Groenendijk L, Toepsch S, Vos P, Salamini F, Schulze-Lefert P. The barley Mlo gene: a novel control element of plant pathogen resistance. Cell 1997;88:695-705.

[3] Collmer A, Lindeberg M, Petnicki-Ocwieja T, Schneider DJ, Alfano JR. Genomic mining type III secretion system effectors in Pseudomonas syringae yields new picks for all TTSS prospectors. Trends Microbiol 2002;10:462-9.

[4] Cui Y, Madi L, Mukherjee A, Dumenyo CK, Chatterjee AK. The RsmA-mutants of Erwinia carotovora subsp. carotovora strain Ecc71 overexpress hrpN $\mathrm{Ecc}_{\mathrm{Ecc}}$ and elicit a hypersensitive reaction-like response in tobacco leaves. Mol Plant Microbe Interact 1996;9:565-73.

[5] Dangl JL. The enigmatic avirulence genes of phytopathogenic bacteria. Curr Top Microbiol Immunol 1994;192:99-118.

[6] Dangl JL, Dietrich RA, Richberg MH. Death don't have no mercy: cell death programs in plant-microbe interactions. Plant Cell 1996;8: 1793-807.

[7] Dayakar BV, Lin HJ, Chen CH, Ger MJ, Lee BH, Pai CH, Chow D, Huang HE, Hwang SY, Chung MC, Feng TY. Ferredoxin from sweet

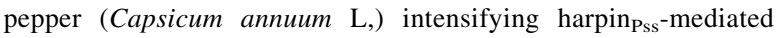
hypersensitive response shows an enhanced production of active oxygen species (AOS). Plant Mol Biol 2003;51:913-24.

[8] Delaney TP, Uknes S, Vernooij B, Friedrich L, Weymann K, Negrotto D, Graffney T, Gut-Rella M, Kessmann H, Ward E, Ryals J. A central role of salicylic acid in plant disease resistance. Science 1994;266:1247-50.

[9] Dixon RA, Lamb CJ, Masoud S, Sewalt VJ, Paiva NL. Metabolic engineering: prospects for crop improvement through the genetic manipulation of phenylpropanoid biosynthesis and defense responses. Gene 1996;179:61-71.

[10] Dietrich RA, Delaney TP, Uknes SJ, Ward ER, Ryals JA, Dangl JL. Arabidopsis mutants simulating disease resistance response. Cell 1994;77:565-77.

[11] Gaffney T, Friedrich L, Vernooij B, Negrotto D, Nye G, Uknes S, Ward E, Kessmann H, Ryals J. Requirement of salicylic acid for the induction of systemic acquired resistance. Science 1993;261:754-6.

[12] Galán JE, Collmer A. Type III secretion machines: bacterial devices for protein delivery into host cells. Science 1999;284:1322-8.

[13] Ger MJ, Chen CH, Hwang SY, Huang HE, Podile AR, Dayakar BV, Feng TY. Constitutive expression of hrap gene in transgenic tobacco 
plant enhances resistance against virulent bacterial pathogens by induction of a hypersensitive response. Mol Plant Microbe Interact 2002;15:764-73.

[14] Gallo-Meagher M, Sowinski DA, Elliott RC, Thompson WF. Both internal and external regulatory elements control expression of the pea $f e d-1$ gene in transgenic tobacco seedlings. Plant Cell 1992;4: 389-95.

[15] Greenberg JT, Guo A, Klessig DF, Ausubel FM. Programmed cell death in plant: a pathogen-triggered response activated coordinately with multiple defense functions. Cell 1994;77:551-63.

[16] He SY, Huang HC, Collmer A. Pseudomonas syringae pv. syringae harpin $P_{\text {ss }}$ : a protein that is secreted via the Hrp pathway and elicits the hypersensitive response in plant. Cell 1993;73:1255-66.

[17] Holsters M, De Waele D, Depicker A, Messens E, Van Montagu M, Schell J. Transfection and transformation of Agrobacterium tumefaciens. Mol Gen Genet 1978;163:182-7.

[18] Horsch RB, Fry JE, Hofmannn NL, Eichholtz D, Rogers SG, Fraley RT. A simple and general method for transferring genes into plants. Science 1985;227:1229-31.

[19] Hoyos ME, Stanley CM, He SY, Pike S, Pu XA, Novacky A. The interaction of harpin ${ }_{\text {Pss, }}$, with plant cell walls. Mol Plant Microbe Interact 1996;9:608-16.

[20] Huang HC, Shuurink R, Denny TP, Atkinson MM, Baker CJ, Yucel I, Hutcheson SW, Collmer A. Molecular cloning of Pseudomonas syringae pv. syringae gene cluster that enable Pseudomonas fluorescens to elicit the hypersensitive response in tobacco plants. J Bacteriol 1988;170:4748-56.

[21] Jana S, Choudhuri MA. Glycolate metabolism of three submerged aquatic angiosperms during aging. Aqua Bot 1982;12:345-54.

[22] Keen NT. Gene-for-gene complementarity in plant-pathogen interactions. Annu Rev Genet 1990;24:447-63.

[23] Laby RJ, Beer SV. Hybridization and functional complementation of the hrp gene cluster from Erwinia amylovora strain Ea321 with DNA of other bacteria. Mol Plant Microbe Interact 1992;5:412-9.

[24] Lamb CJ, Lawton MA, Dron M, Dixon RA. Signals and transduction mechanisms for activation of plant defenses against microbial attack. Cell 1989;5:215-24.

[25] Liau CH, Lu JC, Prasad V, Hsiao HH, You SJ, Lee JT, Yang NS, Huang HE, Feng TY, Chen WH, Chan MT. The sweet pepper ferredoxin-like protein (PFLP) conferred resistance against soft rot disease in oncidium orchid. Transgenic Res 2003;12:329-36.

[26] Lindsay WP, Lamb CJ, Dixon RA. Microbial recognition and activation of plant defense systems. Trends Microbiol 1993;1:181-7.

[27] Malamy J, Carr JP, Klessig DF, Raskin I. Salicylic acid: a likely endogenous signal in the resistance response of tobacco to viral infection. Science 1990;250:1002-4.

[28] Mittler R, Herr EH, Orvar BL, van Camp W, Willekens H, Inze D, Ellis BE. Transgenic tobacco plants with reduced capability to detoxify reactive oxygen intermediates are hyperresponsive to pathogen infection. Proc Natl Acad Sci USA 1999; (96): 14165-70.
[29] Mukherjee A, Cui Y, Liu Y, Chatterjee AK. Molecular characterization and expression of the Erwinia carotovora $h r p N_{E c c}$ gene, which encodes an elicitor of the hypersensitive reaction. Mol Plant Microbe Interact 1997;10:462-71.

[30] Pike SM, Adam AL, Pu XA, Hoyos ME, Laby R, Beer SV, Novacky A. Effects of Erwinia amylovora harpin on tobacco leaf cell membranes are related to leaf necrosis and electrolyte leakage and distinct from perturbations caused by inoculated E. amylovora. Physiol Mol Plant Pathol 1998;53:39-60.

[31] Pontier D, Balagué C, Bezombes-Marion I, Tronchet M, Deslandes L, Roby D. Identification of a novel pathogen-responsive element in the promoter of the tobacco gene $h s r 203 \mathrm{~J}$, a molecular marker of the hypersensitive response. Plant J 2001;26:495-507.

[32] Pontier D, Tronchet M, Rogowsky P, Lam E, Roby D. Activation of $h s r 203 \mathrm{~J}$, a plant gene expressed during incompatible plant-pathogen interactions, is correlated with programmed cell death. Mol Plant Microbe Interact 1998;11:544-54.

[33] Popham P, Pike S, Novacky A. The effect of harpin from Erwinia amylovora on the plasmalemma of suspension-cultured tobacco cells. Physiol Mol Plant Pathol 1995;47:39-50.

[34] Rantakari A, Virtaharju O, Vahamiko S, Taira S, Palva ET, Saarilahti HT, Romantschuk M. Type III secretion contributes to the pathogenesis of the soft-rot pathogen Erwinia carotovora: partial characterization of the hrp gene cluster. Mol Plant Microbe Interact 2001;14:962-8.

[35] Sambrook J, Fritsch EF, Maniatis T., 2nd ed Molecular Clone. A Laboratory Manual, E6. New York, USA: Cold Spring Harbor; 1989 p. 9.31-9.57.

[36] Shen S, Li Q, He SY, Barker KR, Li D, Hunt AG. Conversion of compatible plant-pathogen interactions into incompatible interactions by expression of the Pseudomonas syringae pv. syringae $61 \mathrm{hrmA}$ gene in transgenic tobacco plants. Plant J 2000;23:205-13.

[37] Sutherland MW. The generation of oxygen radicals during host plant responses to infection. Physiol Mol Plant Pathol 1991;39:79-93.

[38] Tang KX, Sun XF, Hu QN, Wu AZ, Lin CH, Lin HJ, Twyman RM, Christou P, Feng TY. Transgenic rice plants expressing the ferredoxinlike protein (AP1) from sweet pepper show enhanced resistance to Xanthomonas oryzae pv. oryzae. Plant Sci. 2001;160:1035-42.

[39] Tampakaki AP, Panopoulos N. Elicitation of hypersensitive cell death by extracellularly targeted HrpZ $Z_{\text {Psph }}$ produced in planta. Mol Plant Microbe Interact 2000;13:1366-74.

[40] Tenhaken R, Levine A, Brisson LF, Dixon RA, Lamb C. Function of the oxidative burst in hypersensitive disease resistance. Proc Natl Acad Sci USA 1995;92:4158-63.

[41] Wei ZM, Laby RJ, Zumoff CH, Bauer DW, He SY, Collmer A, Beer SV. Harpin, elicitor of the hypersensitive response produced by the plant pathogen Erwinia amylovora. Science 1992;257:85-8.

[42] Zeier J, Pink B, Mueller MJ, Berger S. Light conditions influence specific defence responses in incompatible plant-pathogen interactions: uncoupling systemic resistance from salicylic acid and PR-1 accumulation. Planta 2004 in press. PMID15098125. 